\title{
Paramecium bursaria-A Complex of Five Cryptic Species: Mitochondrial DNA COI Haplotype Variation and Biogeographic Distribution ${ }^{+}$
}

\author{
Magdalena Greczek-Stachura ${ }^{1}$, Maria Rautian ${ }^{2}$ and Sebastian Tarcz ${ }^{3, *}$ (D) \\ 1 Institute of Biology, Pedagogical University of Krakow, Podchorażych 2, 30-084 Kraków, Poland; \\ magdalena.greczek-stachura@up.krakow.pl \\ 2 Laboratory of Protistology and Experimental Zoology, Faculty of Biology and Soil Science, \\ St. Petersburg State University, Universitetskaya nab. 7/9, 199034 Saint Petersburg, Russia; mrautian@mail.ru \\ 3 Institute of Systematics and Evolution of Animals, Polish Academy of Sciences, Sławkowska 17, \\ 31-016 Kraków, Poland \\ * Correspondence: tarcz@isez.pan.krakow.pl \\ † urn:lsid:zoobank.org:pub:5E000D59-AC98-4CB5-903E-F0251A01B6A4
}

\section{check for} updates

Citation: Greczek-Stachura, M.; Rautian, M.; Tarcz, S.

Paramecium bursaria-A Complex of Five Cryptic Species: Mitochondrial DNA COI Haplotype Variation and Biogeographic Distribution. Diversity 2021, 13, 589. https://doi.org/ $10.3390 / \mathrm{d} 13110589$

\section{Academic Editors:}

Genoveva F. Esteban and Hunter N. Hines

Received: 16 September 2021

Accepted: 15 November 2021

Published: 18 November 2021

Publisher's Note: MDPI stays neutral with regard to jurisdictional claims in published maps and institutional affiliations.

Copyright: (c) 2021 by the authors. Licensee MDPI, Basel, Switzerland. This article is an open access article distributed under the terms and conditions of the Creative Commons Attribution (CC BY) license (https:/ / creativecommons.org/licenses/by/ $4.0 /)$.

\begin{abstract}
Ciliates are a diverse protistan group and many consist of cryptic species complexes whose members may be restricted to particular biogeographic locations. Mitochondrial genes, characterized by a high resolution for closely related species, were applied to identify new species and to distinguish closely related morphospecies. In the current study, we analyzed 132 sequences of COI mtDNA fragments obtained from $P$. bursaria species collected worldwide. The results allowed, for the first time, to generate a network of COI haplotypes and demonstrate the relationships between $P$. bursaria strains, as well as to confirm the existence of five reproductively isolated haplogroups. The $P$. bursaria haplogroups identified in the present study correspond to previously reported syngens (R1, R2, R3, R4, and R5), thus we decided to propose the following binominal names for each of them: P. primabursaria, P. bibursaria, P. tribursaria, P. tetrabursaria, and P. pentabursaria, respectively. The phylogeographic distribution of $P$. bursaria species showed that $P$. primabursaria and $P$. bibursaria were strictly Eurasian, except for two South Australian P. bibursaria strains. P. tribursaria was found mainly in Eastern Asia, in two stands in Europe and in North America. In turn, P. tetrabursaria was restricted to the USA territory, whereas P. pentabursaria was found in two European localities.
\end{abstract}

Keywords: ciliate protists; cryptic species; Paramecium bursaria complex; biogeography; COI haplotype variability

\section{Introduction}

The presence of cryptic species underlying conserved morphospecies (species identified based on shared morphology) has been found across ciliates. Many of them actually consist of cryptic species complexes. However, the issues concerning the biodiversity and biogeography of these species, as well as the determination of interspecific boundaries, remain one of the most important contemporary problems in protistology [1-4]. The possibilities of solving the above problems have increased significantly in recent decades, mainly due to the dynamic development of molecular biology techniques [5-9]. The main result of the application of molecular tools was the identification of a high genetic variation within individual species [10-12], which led to the description of many new species in recent years [7,13-19]. Moreover, the analysis of molecular variability in many cases was the only way to ascertain the existence of cryptic diversity within individual morphospecies $[11,12,20]$. In the genus Paramecium (Protista, Ciliophora, and Oligohymenophorea), new morphospecies like P. ossipovi [21], P. buetschlii [16], P. grohmannae [22], and P. caudatum pakistanicus [23], as well as cryptic species such as P. primjenningsi, P. bijenningsi, P. trijenningsi [24], and 
P. quindecaurelia [25], have been recently described. Based on morphological features (morphological species concept), almost 20 morphospecies of the genus Paramecium have been classified into the following five subgenera: Viridoparamecium, Chloroparamecium, Cypriostomum, Helianter, and Paramecium [16,26,27]. Presumably, most of Paramecium morphospecies consist of cryptic species [24,28-31], which, due to their reproductive isolation, are biological species (biological species concept) [32]. Finally, the application of molecular delimitation mainly based on rDNA or mtDNA markers (phylogenetic species concept) allowed for effective verification of the above taxonomic hypotheses based on genetic distances and strong bootstrap support, which confirmed the existence of independent evolutionary lineages and made it possible to distinguish new taxa [16,23].

Determining the boundaries between individual ciliate taxa is difficult due to the complex species structure [33], the lack of samples from many ecosystems [34], and the proper selection of a DNA marker, especially when systematic identification in environmental DNA biodiversity surveys is based solely on molecular markers [35]. Despite the application of various DNA markers (ribosomal, mitochondrial, and nuclear), previous studies have shown that a fragment of cytochrome $c$ oxidase subunit I-COI mtDNA should be the most promising tool for species identification in ciliates (including the genus Paramecium) [29,36-38].

Paramecium bursaria [39], studied in the current survey, is the only morphospecies in the subgenus Chloroparamecium and has a foot-shaped (similar to the imprint of a foot) cell of 80-150 $\mu \mathrm{m}$ with a compact type micronucleus. The species is relatively wide and short, being obliquely truncated or rounded anteriorly, broadly rounded posteriorly, and dorsoventrally compressed. Presumably, this species is distributed worldwide and is commonly found in ponds, streams, and other freshwater habitats $[40,41]$. A distinctive feature of this species is mutualistic endosymbiosis with some species of green algae [42,43]. Bomford [44] described the taxonomy of P. bursaria and documented six syngens (the term syngen has remained in use for P. bursaria) within this species. The syngens are reproductively isolated from each other. In cases where intersyngenic mating is observed, exconjugant cells die without dividing, so that reproductive isolation is maintained through F1 inviability [44,45]. Each P. bursaria syngen has a characteristic number of mating types, and the syngens have specific geographic distributions. Since the Bomford collection was lost, a new syngen numbering has been proposed based on a new representative collection of $P$. bursaria strains [29].

In the present study, we investigated 132 COI sequences obtained from P. bursaria strains classified into five syngens that were collected in remote geographic locations. COI sequences for 101 strains were obtained from the GenBank database, whereas 31 COI gene fragments were sequenced for the first time. On the basis of the obtained COI dataset, we were able to present phylogenetic relationships between $P$. bursaria syngens and to rename them by proposing binominal names as in other Paramecium cryptic species complexes [24,28]. Furthermore, this was the first attempt to analyze the distribution of P. bursaria with the use of haplotype networks to assess the biogeography of individual cryptic species of the complex.

\section{Materials and Methods}

\subsection{Material}

The origin of ciliate strains studied in the current work is presented in Figure 1 and Table S1 (Supplementary Material). Clonal cultures of all these strains were deposited in CCCS (Culture Collection of Ciliates and their Symbionts, Collection registered in WFCC, $\# 1024)$ at the St. Petersburg State University. 


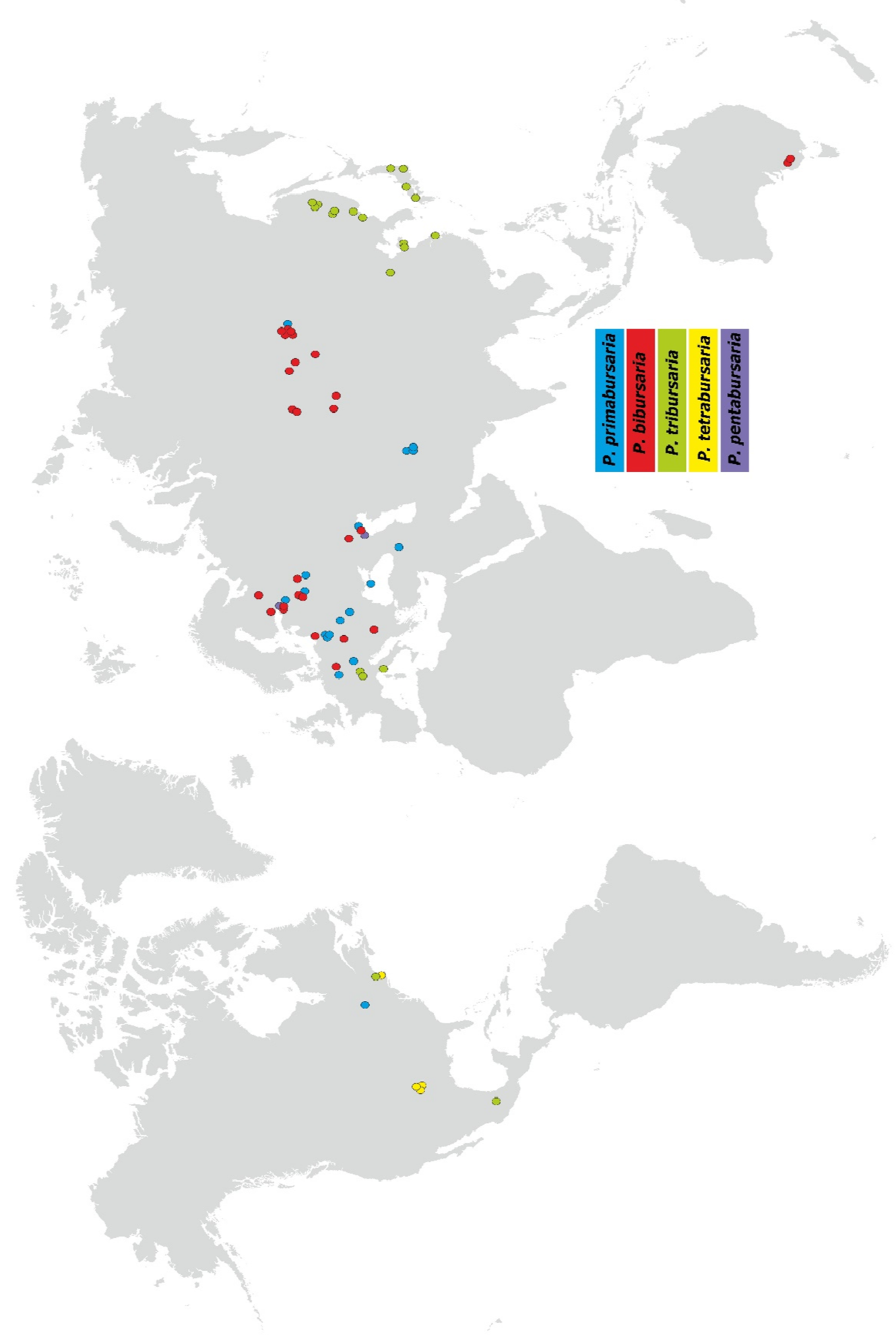

Figure 1. Geographic distribution of cryptic species of the Paramecium bursaria complex. 


\subsection{Methods}

\subsubsection{Culturing and Identification of P. bursaria Strains}

Strains of Paramecium bursaria were obtained from the Culture Collection of Ciliates of St. Petersburg University. To prepare the cell culture for DNA isolation, paramecia were grown on lettuce medium inoculated with Enterobacter aerogenes. One volume of KK (Karakashian and Karakashian) buffer was added to two volumes of medium before feeding [46]. Ciliates were incubated at a temperature of $18{ }^{\circ} \mathrm{C}$ in the daily cycle of 12 light hours and 12 dark hours (12L/12D) in climate chambers (Angelantoni Life Science, Italy). The light intensity was $200 \mu \mathrm{mol} \mathrm{m}{ }^{-2} \mathrm{~s}^{-1}$ and was maintained using a quantum sensor (model 189, Li-Cor, Inc., Lincoln, NE, USA). Syngen identification was performed by mating reactions of a strain of interest with standard strains representing all mating types of each syngen. The strain of interest was assigned to a certain syngen based on the strong clumping at the beginning of the mating reaction, observed mating couples, and survival of $\mathrm{F}_{1}$ progeny. The origin of standard strains deserves special attention. All standard strains for syngens R1 and R2 were originally developed in the 1980s from a collection of stocks of unknown syngens using the round-robin mating test; strains of all eight mating types of syngen R1 were isolated from a population collected in Peterhof, a suburb of St. Petersburg; strains of all eight mating types of syngen $\mathrm{R} 2$ were isolated from a population collected in Lake Ladoga on Valaam Island. Four strains representing different mating types of syngen B1 were obtained from Prof. I. Miwa in the mid-1990s, and as it was the third syngen in the Russian collection, it was assigned the symbol "R3". Strains of different mating types in syngens R4 and R5 were identified based on the results of mating with standard strains of syngens R1-R3 and the results of round-robin mating tests. The set of standard strains is a matter of step-by-step substitutions, as P. bursaria strains lose their ability to actively mate with age. No microscopy characteristics was conducted.

\subsubsection{Molecular Techniques}

Genomic DNA of Paramecium was isolated (approximately 1000 cells were used for DNA extraction) from vegetative cells at the end of the exponential phase using the NucleoSpin Tissue Kit (Macherey-Nagel, Düren, Germany), according to the manufacturer's instructions for DNA isolation from human or animal tissue and cultured cells. The only modification was cell culture centrifugation for $20 \mathrm{~min}$ at 13,200 rpm. Then, the supernatant was removed and the remaining cells were resuspended in a lysis buffer and proteinase $\mathrm{K}$. The proteinase $\mathrm{K}$ buffer step consisted of two parts: pre-lyse sample incubation at $56{ }^{\circ} \mathrm{C}$ for $3 \mathrm{~h}$ and lyse sample incubation at $70^{\circ} \mathrm{C}$ for $10 \mathrm{~min}$. The protocol details are available at https://www.mn-net.com/media/pdf/5b/d0/d9/Instruction-NucleoSpin-Tissue.pdf (accessed on 8 November 2021). Both the quantity and purity of the extracted DNA were evaluated using a NanoDrop-2000 spectrophotometer (Thermo Scientific, Waltham, MA, USA).

Fragments of the COI gene were amplified, sequenced, and analyzed. The COI fragment of mitochondrial DNA was amplified using a pair of primers, namely forward F388dT (5'-TGTAAAACGACGGCCAGTGGwkCbAAAGATGTwGC- $3^{\prime}$ ) and reverse R1184dT (5'-CAGGAAACAGCTATGACTAdACyTCAGGGTGACCrAAAAATCA-3'), and a protocol previously described in [36]. The amplification cycles were as follows: $4 \mathrm{~min}$ at $94{ }^{\circ} \mathrm{C}$, followed by 5 cycles of $94{ }^{\circ} \mathrm{C}$ for $45 \mathrm{~s}, 45^{\circ} \mathrm{C}$ for $75 \mathrm{~s}$, and $72{ }^{\circ} \mathrm{C}$ for $90 \mathrm{~s} ; 30$ cycles of $94{ }^{\circ} \mathrm{C}$ for $45 \mathrm{~s}, 55{ }^{\circ} \mathrm{C}$ for $75 \mathrm{~s}$, and $72{ }^{\circ} \mathrm{C}$ for $90 \mathrm{~s}$; and a final extension at $72{ }^{\circ} \mathrm{C}$ for $8 \mathrm{~min}$. PCR amplification was carried out in a final volume of $40 \mu \mathrm{L}$ containing $30 \mathrm{ng}$ DNA, $1.5 \mathrm{U}$ Taq polymerase (EURx, Poland), $0.8 \mu \mathrm{L}$ of $20 \mu \mathrm{M}$ each primer, $10 \mathrm{X}$ PCR buffer, and $0.8 \mu \mathrm{L}$ of $10 \mathrm{mM}$ dNTPs. In order to assess the quality of amplification, PCR products were electrophoresed in $1 \%$ agarose gel for $30 \mathrm{~min}$ at $85 \mathrm{~V}$ with a DNA molecular weight marker (MassRuler Low Range DNA Ladder, Thermo Fisher Scientific, Waltham, MA, USA).

To purify the PCR products, $5 \mu \mathrm{L}$ of each product was mixed with $2 \mu \mathrm{L}$ of Exo-BAP Mix (EURx, Gdańsk, Poland), and was subsequently incubated at $37^{\circ} \mathrm{C}$ for $15 \mathrm{~min}$, followed by another $15 \mathrm{~min}$ at $80^{\circ} \mathrm{C}$. Cycle sequencing was performed in both directions using BigDye Terminator v3.1 chemistry (Applied Biosystems, Waltham, MA, USA). The forward M13F 
(5'-TGTAAAACGACGGCCAGT-3') and reverse M13R (5'-CAGGAAACAGCTATGAC-3') primers [36] were used for sequencing the $C O I$ fragment. Details of the sequencing procedure are derived from [30]. The studied COI sequences are available in the NCBI GenBank database (see Supplementary Table S1).

\subsubsection{Data Analysis}

Sequences were evaluated and chromatograms corrected using Chromas Lite v2.1.1 (Technelysium, Brisbane, Australia). Alignment of the studied COI mtDNA fragment was performed using BioEdit v7.2.5 software [47] and was checked manually. All sequences obtained were unambiguous and were used for further analyses. Mean uncorrected p-distances were calculated using Mega v6.0 [48]. Neighbor joining (NJ), maximum parsimony (MP), and maximum likelihood (ML) analyses were performed using Mega v6.0 program by bootstrapping with 1000 replicates. All of the positions containing gaps and missing data were eliminated. MP analysis was evaluated with the min-min heuristic parameter (at level 2) and bootstrapping with 1000 replicates. An $\mathrm{HKY}+\mathrm{G}+\mathrm{I}$ model for mtDNA ( $G=0.758, I=0.198)$ was identified as the best nucleotide substitution model for maximum likelihood tree reconstruction using Mega v6.0 software. Bayesian inference (BI) was performed using MrBayes v3.1.2 [49]; the analysis was run for 5,000,000 generations with the GTR+G+I model, and trees were sampled every 100 generations. All of the trees for the BI analysis were visualized using TreeView v1.6.6 [50].

The number of haplotypes (h), intraspecific haplotype diversity $(\mathrm{Hd})$, and the nucleotide diversity $(\pi)$ were determined with DnaSP v5.10.01 [51]. The haplotype network, representing the distribution and relationships among haplotypes of Paramecium bursaria strains, was reconstructed using the Median Joining method [52] implemented in PopART v1.7 software [53].

\section{Results}

\subsection{Paramecium bursaria Species Complex}

The current study revealed the existence of five distinct clades (Figures 2-4), which correspond to five P. bursaria syngens previously proposed by Greczek-Stachura et al. [29]. Therefore, to organize the nomenclature of P. bursaria-like taxa, confirmed by molecular methods and determined by strain crosses, as in other species complexes of the genus Paramecium (P. aurelia and P. jenningsi), we proposed the following nomenclature of syngens R1, R2, R3, R4, and R5: Paramecium primabursaria (former syngen R1), Paramecium bibursaria (former syngen R2), Paramecium tribursaria (former R3 syngen), Paramecium tetrabursaria (former syngen R4), and Paramecium pentabursaria (former syngen R5), respectively. When describing successive members of the $P$. bursaria complex, specific names should be created by adding a numerical prefix, similarly as for the P. aurelia complex [28] (for details see below Taxonomic summary, a subsection in the Discussion chapter).

\subsection{Analysis of COI mtDNA Sequences of the Paramecium bursaria Complex}

In the current survey, we studied a total of 132 sequences of COI mtDNA fragments obtained from P. bursaria strains collected in Europe, Asia, North America, and Australia (Figure 1 and Table S1). Additional GenBank records for other Paramecium subgenera and two Tetrahymena species (used as an outgroup) were included in phylogenetic COI tree reconstructions, thus, ultimately 215 mitochondrial DNA sequences were used (for details, see Table S2). After trimming, we used the mtDNA region containing cytochrome c oxidase subunit I (626-638 nt long depending on species) for the purpose of sequence comparison.

The intraspecific haplotype diversity (Hd) of the morphospecies P. bursaria was 0.966 for COI $(n=132)$, which indicates a significant differentiation within the P. bursaria species complex. Individual species were, however, characterized by a much lower intraspecific haplotype diversity (Hd) of 0.01 (Table 1 ). Within the studied P. bursaria complex, we identified 63 COI haplotypes, which were divided into individual cryptic species as follows: 9 haplotypes belonging to $P$. primabursaria, 18 haplotypes to P. bibursaria, 31 haplotypes to 
P. tribursaria, 3 haplotypes to P. tetrabursaria, and 2 haplotypes to P. pentabursaria (Figure 3). Mutual relationships between haplotypes are presented later in the text. Details of DNA sequence variations among all of the studied cryptic species are shown in Table 1 and Table S3.

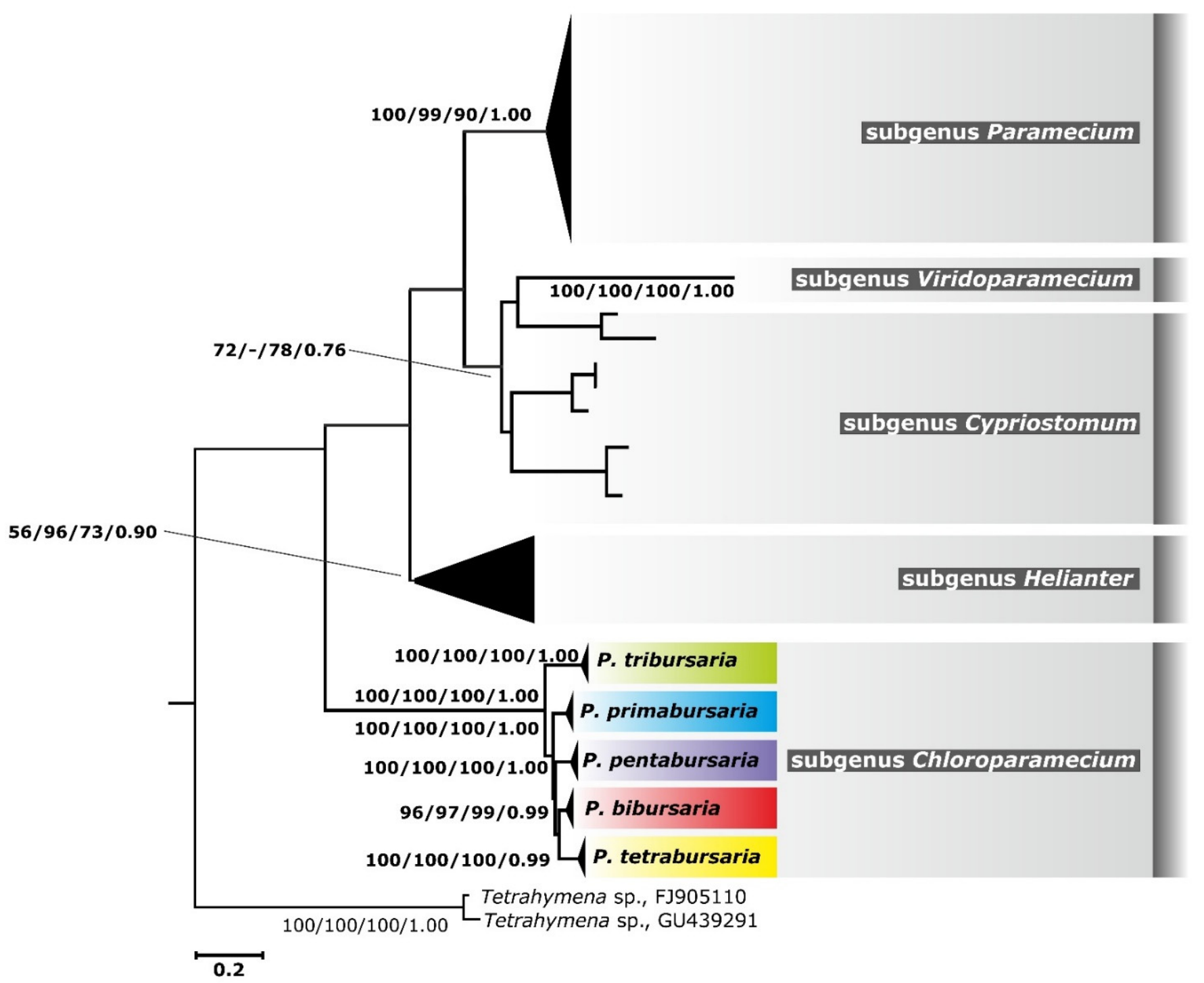

Figure 2. Phylogenetic tree constructed for 132 Paramecium bursaria strains and other Paramecium subgenera (two Tetrahymena species are used as an outgroup). The tree is built on the basis of the mitochondrial COI fragment using the Maximum Likelihood method (ML). Bootstrap values for neighbor joining (NJ), maximum parsimony (MP), maximum likelihood (ML), and posterior probabilities for Bayesian inference (BI) are presented. Bootstrap values lower than 50\% (posterior probabilities < 0.50) are not shown. Dashes represent no bootstrap or a posterior value at a given node. All positions containing gaps and missing data are eliminated. Phylogenetic analyses are conducted using MEGA v6.0 (NJ/MP/ML) and MrBayes 3.1.2 (BI). The analysis involved 215 nucleotide sequences. There are 649 positions in the final dataset.

It is worth noting that the uncorrected p-distances within the P. bursaria complex are comparable to or even greater than those observed for species from the $P$. aurelia and P. jenningsi complexes (Table 1). The current study suggests that the COI mtDNA fragment is a good diagnostic tool for cryptic species identification in the P. bursaria species complex. 


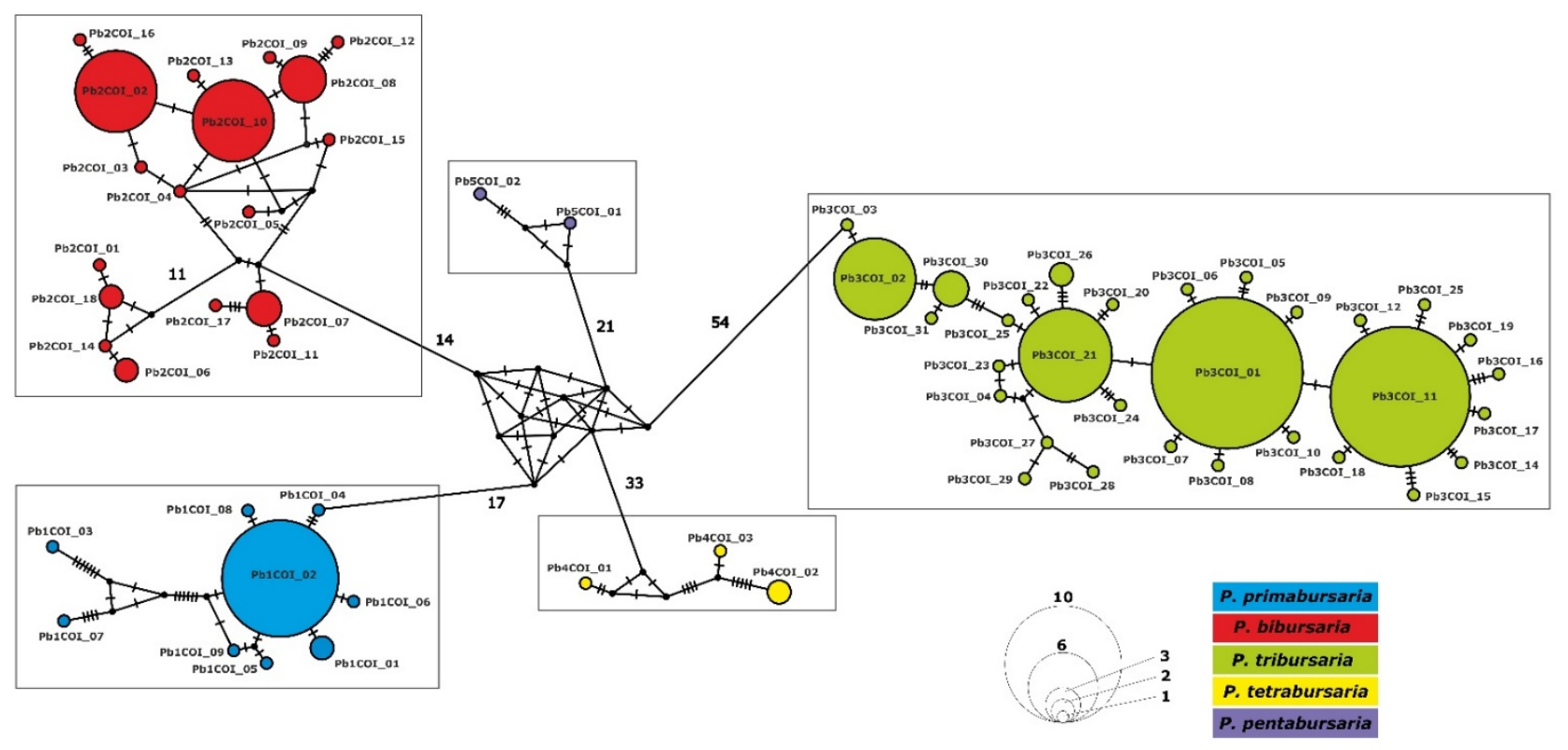

Figure 3. Haplotype network of the Paramecium bursaria complex constructed using 132 mitochondrial COI gene sequences. The network presents interrelationships among P. bursaria strains. Hatch marks on individual branches represent nucleotide substitutions (the corresponding number is provided for more than 10 substitutions). Analyses are conducted using the median joining method in PopART software v. 1.7.

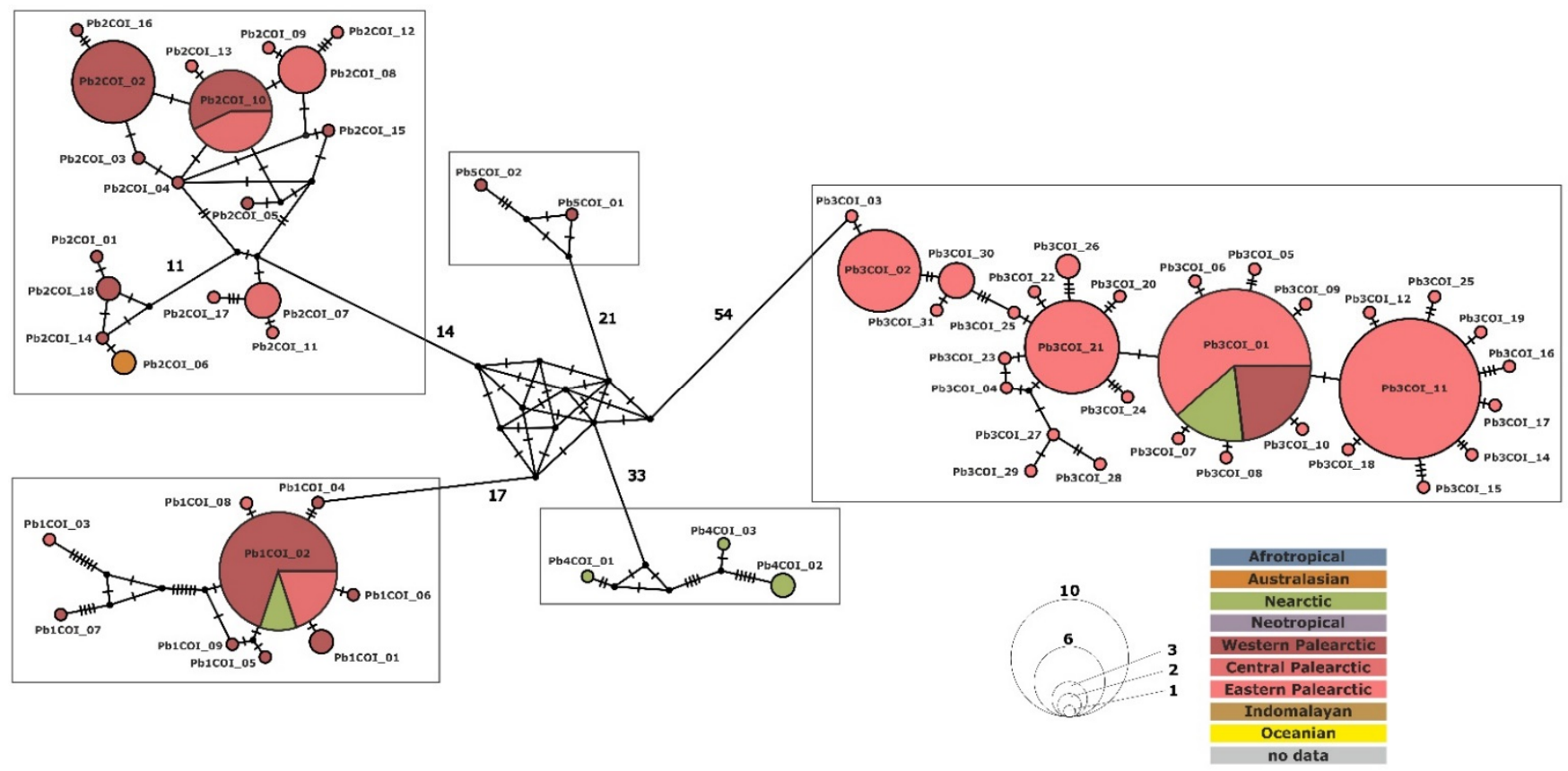

Figure 4. Haplotype network of the Paramecium bursaria complex constructed using 132 mitochondrial COI gene sequences. The network presents the origin and interrelationships among P. bursaria strains. Hatch marks on particular branches represent nucleotide substitutions (the corresponding number is provided for more than 10 substitutions). Analyses are conducted using the median joining method in PopART software v. 1.7. 
Table 1. DNA sequence variability of species from the Paramecium bursaria complex in comparison with the Paramecium aurelia and Paramecium jenningsi species complexes.

\begin{tabular}{|c|c|c|c|c|c|}
\hline $\begin{array}{l}\text { Paramecium } \\
\text { Species }\end{array}$ & $\begin{array}{c}\text { Number of } \\
\text { Sequences } \\
\mathbf{N}\end{array}$ & $\begin{array}{c}\text { Mean } \\
\text { Uncorrected } \\
\text { p-Distance }\end{array}$ & $\begin{array}{c}\text { Number of } \\
\text { Haplotypes } \\
\text { h }\end{array}$ & $\begin{array}{c}\text { Haplotype } \\
\text { Diversity } \\
\text { Hd }\end{array}$ & $\begin{array}{c}\text { Nucleotide } \\
\text { Diversity } \\
\pi\end{array}$ \\
\hline P. primabursaria & 19 & 0.01 & 9 & 0.731 & 0.00552 \\
\hline P. bibursaria & 37 & 0.01 & 18 & 0.920 & 0.0000029 \\
\hline P. tribursaria & 70 & 0.01 & 31 & 0.918 & 0.00533 \\
\hline P. tetrabursaria & 4 & 0.01 & 3 & 0.833 & 0.01133 \\
\hline P. pentabursaria & 2 & 0.01 & 2 & 1.000 & 0.00618 \\
\hline P. bursaria complex & 132 & 0.09 & 63 & 0.966 & 0.06351 \\
\hline $\begin{array}{l}\text { P. jenningsi } \\
\text { complex * }\end{array}$ & 13 & 0.013 & 13 & 1.000 & 0.01779 \\
\hline P. aurelia complex* & 15 & 0.084 & 15 & 1.000 & 0.07812 \\
\hline
\end{tabular}

${ }^{*}$-data obtained from [24].

\subsection{Phylogenetic Relationship and Haplotype Analysis}

Phylogenetic reconstruction based on 213 COI mtDNA fragments of all Paramecium species (Tables S1 and S2) revealed relationships among the 132 studied strains of the P. bursaria complex, as well as their position relative to other members of the genus Paramecium. All methods (NJ, MP, ML, and BI) of tree reconstruction showed a similar topology, thus we decided to present only the maximum likelihood phylogram (Figure 2) providing bootstrap/posterior probability values for the other methods used. The former P. bursaria clade (according to the present proposal of the P. bursaria species complex) was found to be distinct from other species of the genus Paramecium. In addition, it could be divided into two clades: one clade with the most distant $P$. tribursaria and the second clade containing all other species of the complex. It can be noticed that P. bibursaria and P. tetrabursaria are sister subclades in the second clade.

We constructed a haplotype network to examine interspecific relationships within the P. bursaria complex in more detail (Figures 3 and 4). The first COI network (Figure 3) presents mutual relationships among $P$. bursaria strains and indicates the existence of five well-separated haplogroups, corresponding to individual cryptic species. Generally, P. bursaria-like species are separated from each other by as many as $68-87$ different nucleotides. Haplotypes within individual cryptic species differ from each other by 1 to 22 substitutions (Figure 3). The second network (Figure 4) presents the distribution of haplotypes in terms of the biogeography of the P. bursaria species complex.

\subsection{Paramecium bursaria Complex Biogeography - Analysis of Haplotype Variability}

As mentioned above, the analysis of intraspecific variation within the P. bursaria complex revealed the existence of 63 COI haplotypes (Figures 3 and 4), which could be divided into five haplogroups corresponding to five cryptic species: P. primabursaria (haplotypes Pb1COI_01-09), P. bibursaria (haplotypes Pb2COI_01-18), P. tribursaria (haplotypes Pb3COI_01-31), P. tetrabursaria (haplotypes Pb4COI_01-03), and P. pentabursaria (haplotypes Pb5COI_01-02). It should be noted that P. primabursaria, P. bibursaria, and P. tribursaria have one to four haplotypes that are characterized by a wide-range (sometimes intercontinental) distribution, whereas most haplotypes are usually restricted to one location (Figure 4). Overall, most of the studied haplotypes were identified as Palearctic (for better orientation, a division was introduced into the Western, Central, and Eastern Palearctic biogeographic ecozones), five were from the Nearctic biogeographic ecozone (Pb1COI_02, Pb3COI_01, Pb4COI_01-03) and one from the Australasian biogeographic ecozone (Pb2COI_06). An evaluation of the geographic distribution of the P. bursaria complex has shown that two cryptic species, $P$. tetrabursaria and P. pentabursaria, have a limited range, while the other species have a wider range of occurrence (Figure 1). P. tribursaria occurs mainly in Southeast Asia, plus two stands from Europe and two from North America. 
P. primabursaria and P. bibursaria are found mainly in Europe and Central Asia. The only exception concerning P. bibursaria are two stands from Southern Australia. It is worth noting that $P$. tetrabursaria has so far been found only in North America (Nearctic biogeographic ecozone), while P. pentabursaria has been found in Western Russia (Palearctic biogeographic ecozone) (Table S1). Therefore, it can be assumed that some cryptic species of the P. bursaria complex differ to some extent in their ranges. Locations where two to three species of the P. bursaria complex were identified were rather rare (Figure 1): Astrakhan Nature Reserve or St. Petersburg and St. Petersburg surroundings were areas where P. primabursaria, P. bibursaria, and P. pentabursaria were found. However, ciliates (P. pentabursaria) in the St Petersburg Botanical Garden could have been introduced with plants from other locations.

\section{Discussion}

\subsection{COI mtDNA as an Appropriate DNA Marker for Ciliate Species Delimitation}

Almost 20 years ago, the idea of DNA barcoding (using the COI mtDNA gene fragment) was introduced into the scientific literature [54]. It was the first, widely known attempt to improve the taxonomic research. It quickly became apparent that there was no single universal DNA barcode for all living organisms [55]. Similarly, different markers have also been proposed for ciliates as the most appropriate tools for DNA barcoding $[36,56,57]$. For the genus Paramecium, two molecular markers are usually applied: different fragments of the nuclear rDNA [58-60] and the mitochondrial COI gene fragment $[38,61]$. However, it was demonstrated that in some cases, the more conserved rDNA fragments could lead to ambiguous results in taxonomic studies [38]. Mitochondrial genes generally evolve 5 to 10 times faster than nuclear genes [62] and are, therefore, more suitable molecular markers for closely related organisms, as has also been confirmed in ciliates belonging to the genus Paramecium [63]. Our previous study [29] indicated that only the application of COI allowed for distinguishing five syngens among the 26 studied P. bursaria strains. Based on the previous results, we decided to select this DNA fragment for the current comparative analysis of 132 sequences clustered into 63 haplotypes (Table S1).

\subsection{Cryptic Species in the Genus Paramecium}

Identifying species and determining their systematic position using molecular data are still interesting goals for evolutionary biologists. This work is particularly significant in closely related taxa, especially cryptic species, which are often indistinguishable based on morphological features [64]. The presence of such species has been reported in both multicellular $[65,66]$ and unicellular organisms $[67,68]$, including ciliates [69,70]. In the case of the latter, it is believed that almost $90 \%$ of the species have not yet been described [71]. Therefore, it is conceivable that the identification of cryptic species may significantly help in the assessment of ciliate biodiversity (as well as other microbial eukaryotes).

The presence of reproductively isolated groups, initially called syngens, was observed in the genus Paramecium, i.e., P. aurelia [45] and P. bursaria [44]. Later, syngens in P. aurelia were designated as sibling (cryptic) species based on isoenzyme pattern analysis [72,73] and strain crosses [28]. According to the biological species concept [32], cryptic species of the P. aurelia complex can be identified by mating reactions (conjugation) with standard strains [46]. Previous results, based on molecular analyses, have suggested that cryptic species are quite common in the genus Paramecium, not only in the P. aurelia and P. jenningsi complexes [24,74], but also in other morphospecies where the existence of cryptic species has not been formally described: P. multimicronucleatum [60], P. putrinum [30] and P. calkinsi, and P. nephridiatum [31]. Similarly, as in P. bursaria, molecular analyses of COI mtDNA fragments showed the existence of five clusters that corresponded to five syngens determined earlier based on the results of the mating reactions $[29,75]$. The current study, performed on 132 strains, confirmed the division into five clusters. Moreover, intraspecific analyses (Figures 3 and 4, and Table 1) have demonstrated that molecular genetic distances between individual clusters are similar to those between cryptic species clusters in the P. aurelia and $P$. jenningsi complexes [24]. Therefore, we suppose that it will be appropriate to give 
binominal names to the five clearly distinct $P$. bursaria syngens and to simultaneously name the former P. bursaria [39], the Paramecium bursaria species complex (for details see below Taxonomic summary, a subsection in the Discussion section). The studied species meet the criteria of a species complex [64] because they can be differentiated based on strain crosses and molecular characteristics, but cannot be distinguished solely on the basis of their morphological features. It should be noted that each cryptic species is reproductively isolated and molecularly distant, and based on up-to-date sampling, seems to have a different geographic range [29].

\subsection{Paramecium bursaria Species Complex-Wide or Narrow Range Species?}

Microbial biogeography has been the subject of intense debate for several years [71,76]. There are two distribution models-the cosmopolitan model [2,77] and the moderate endemicity model [71,78]. According to Finlay's hypothesis, the high abundance of individuals observed within populations, short generation times, and high dispersal rates result in the absence of geographical barriers for particular species. In turn, the moderate endemicity model of ciliate biogeography indicates that two-thirds of protists may be distributed globally. However, some protist species are restricted to a specific region or area, i.e., they exhibit "local endemism" [78-80].

In the genus Paramecium, a narrow occurrence range is characteristic of $P$. tredecaurelia, P. sonneborni, or P. quindecaurelia, which are known from one to several locations $[25,81,82]$, whereas $P$. biaurelia or $P$. tertaurelia are found worldwide [83]. Similarly, two distribution patterns are observed in the $P$. jenningsi complex, where $P$. trijennngsi has a wide range of occurrence, whereas P. primjenningsi and P. bijenningsi are restricted to two to three sampling sites [38]. Sonneborn [45] compared Paramecium species, considering features such as mating type inheritance, immaturity interval, maturity period, autogamy, selfing, and fission rate, as well as geographic distribution and proposed an inbreeding-outbreeding continuum. P. bursaria, which represents extreme outbreeders (many mating types, long periods of maturity and immaturity, low fission rate), is supposed to be a widespread taxon. Based on our list of sampling sites, we observed both narrow (P. tetrabursaria and $P$. pentabursaria) and wide range (P. primabursaria, $P$. bibursaria, and $P$. tribursaria) cryptic species. We are aware that the biogeographic division might be different, as the current analyses are limited to 56 locations (Table S1). Most of them were situated in the Western Palearctic biogeographic ecozone (27), followed by the Eastern Palearctic biogeographic ecozone (14), the Central Palearctic biogeographic ecozone (10), the Nearctic biogeographic ecozone (4), and finally the Australasian biogeographic ecozone (1). The presence of P. bursaria cryptic species in biogeographic ecozones such as Afrotropical, Neotropical, Indomalayan, and Oceanian zones has not been confirmed so far, which may be related to the relatively poorly sampled tropical areas. Interestingly, the only locality of the P. bursaria complex in the Australasian biogeographic ecozone is in the southern part of the continent, where the climate is close to moderate. Thus, up-to-date Paramecium species sampling has shown that the P. bursaria complex is widely distributed in moderate climates, and it has not been found in the tropics. This hypothesis may be supported by the fact that $P$. bursaria strains with endosymbiotic algae show higher growth rates at lower temperatures, while P. bursaria strains without algae exhibit higher growth rates at higher temperatures $[84,85]$. However, it is still likely that more intensive sampling in the tropical zone could change the biogeographic pattern of individual species of the P. bursaria complex. It can be assumed that temperature is one of the most important factors affecting the occurrence of species of the genus Paramecium. For example, cryptic species of the P. jenningsi complex were mainly found in the tropics [38]. The P. aurelia complex comprises cosmopolitan species that inhabit areas ranging from cold to tropical ( $P$. primaurelia), non-tropical, widespread species (P. biaurelia), as well as species occurring in warm climates (P. quadecaurelia and P. sonneborni) [81,82].

Phylogenetic network analysis has shown that there are one to four dominant haplotypes in the case of P. primabursaria, P. bibursaria, and P. tribursaria. Some of them 
show a wide, even intercontinental distribution, for example Pb1COI_02 or Pb3COI_01. The remaining haplotypes mainly have a narrow distribution restricted to one locality. The existence of similar haplotype network patterns (one to four dominant haplotypes and most haplotypes from a single locality) have been observed in P. biaurelia [86] or in P. trijenningsi [38]. This may indicate the absence of geographic barriers and the relatively rapid spread of closely related $P$. bursaria populations, with temperature being a key factor. Most importantly, the division into five haplogroups (Figures 3 and 4 ) does not correspond to the results obtained for the endosymbiotic algae inhabiting the studied species, i.e., the correlation between P. bursaria cryptic species and endosymbiont species, as well as between endosymbiont species and geographic distribution. It can therefore be assumed that the emergence of species within the P. bursaria complex was an earlier event than the association of individual ciliate species with endosymbiont species [42].

\subsection{Taxonomic Summary}

Class Oligohymenophorea de Puytorac et al., 1974 [87]

Order Peniculida Fauré-Fremiet (in Corliss), 1956 [88]

Family Parameciidae Dujardin, 1841 [89]

Genus Paramecium O.F. Müller, 1773 [90]

Subgenus Chloroparamecium Fokin et al., 2004 [26]

Paramecium bursaria Focke, 1836 [39]

The Paramecium bursaria species complex Greczek-Stachura et al., 2021 [42]

Desciption of the morphospecies Paramecium bursaria

Etymology. The name is derived from the Latin word bursa (purse), which refers to the shape of the cell.

Morphological Description (after literature data): Paramecium bursaria has a footshaped cell (similar to the imprint of a foot) with length of $140 \mu \mathrm{m}$ and a width of about $60 \mu \mathrm{m}$. Cells are flat, with an obliquely truncated anterior end at the level of the wide oral groove and a broadly rounded posterior end. Length: 80-150 $\mu \mathrm{m}$, width: 40-56 $\mu \mathrm{m}$. One micronucleus, of compact type, relatively large (length: $25 \mu \mathrm{m}$, width: $11 \mu \mathrm{m}$ ). The single micronucleus belongs to the "compact b" type and its size is $14 \mu \mathrm{m}$ in length and $7 \mu \mathrm{m}$ in width. Two contractile vacuoles (CV) are located close to the dorsal surface in the endoplasm directly beneath the cortex. The CV are of the "canal fed" type, with long collecting vesicles and several excretory pores in each vacuole. The pores connect the CVs to the exterior environment and are located in the cortex; the number of the pores per CV in a species is a distinctive feature [91]. Caudal cilia are present, approximately $18 \mu \mathrm{m}$ in length. The direction of rotation during swimming is counterclockwise. The cell is packed tightly with unicellular symbiont algae. The average number of symbiotic algae is 590 per cell and depends on light conditions. Phylogenetic analyses have revealed that Paramecium bursaria harbors endosymbionts representing different species [42]. It is the "green" Paramecium, which can be easily recognized by its color. P. bursaria exposed to photosynthetically active radiation $(400-700 \mathrm{~nm})$ exhibited the photoaccumulation phenomenon [92,93]. The photoreceptor of P. bursaria is a rhodopsin-like protein located on the anteroventral side, specifically within the oral groove of the cell [94]. It is the freshwater species. It is characterized by extreme outbreeding [22] and a wide geographic distribution. The morphospecies $P$. bursaria is divided into five syngens (species) with four to eight mating types for each syngen (species) [10]. The P. bursaria strain collection is located at the University of St. Petersburg. The current molecular identification of the species from the $P$. bursaria complex based on sequencing of the COI mtDNA fragment confirmed the existence of five species.

Paramecium primabursaria nov. spec.

Holotype: 87 MS-1.

Type locality: St Petersburg vicinity, Russia ( $59^{\circ} 52^{\prime}$ N 29 $54^{\prime}$ E), a pond in park.

Distribution: widespread in Europe, several locations in Asia, including the Baikalarea (easternmost location). 
Occurrence/number of mating types: eight mating types.

May correspond to Bomford's syngen B6.

Gene sequence: cytochrome $c$ oxidase subunit I sequence of the holotype specimen. Has been deposited in GenBank under OK356526 accession number.

Paramecium bibursaria nov. spec.

Holotype: Ek.

Type locality: St Petersburg, Russia $\left(59^{\circ} 58^{\prime} \mathrm{N} 30^{\circ} 14^{\prime} \mathrm{E}\right)$, a pond in a public garden.

Distribution: widespread in Europe, and central part of in Asia, two localities in South Australia.

Occurrence/number of mating types: eight mating types.

Demonstrate very good intersyngenic mating reactions with $P$. tetrabursaria, which suggests that it corresponds to Bomford's syngen B4.

Gene sequence: cytochrome $c$ oxidase subunit I sequence of the holotype specimen. Has been deposited in GenBank under JF708911 accession number.

Paramecium tribursaria nov. spec.

Holotype: T316.

Type locality: Tsukuba, Japan $\left(36^{\circ} 03^{\prime} \mathrm{N} 140^{\circ} 07^{\prime} \mathrm{E}\right)$ no habitat details.

Distribution: widespread in eastern Asia (Russia, Japan, China), three locations in southern

Europe, and one in North America (Boston, MA, USA).

Occurrence/number of mating types: eight mating types.

It is still maintained in several laboratories in Japan, and these strains were once used for the identification of strains from the current collection. That makes it the only link to the lost Bomford's collection.

Corresponds to Bomford's syngen B1.

Gene sequence: cytochrome $c$ oxidase subunit I sequence of the holotype specimen. Has been deposited in GenBank under JF708900 accession number.

Paramecium tetrabursaria nov. spec.

Holotype: AB2-32.

Type locality: Boston, USA $\left(42^{\circ} 21^{\prime} \mathrm{N} 71^{\circ} 04^{\prime} \mathrm{W}\right)$, a pond in public garden.

Distribution: restricted to USA area.

Occurrence/number of mating types: six mating types.

Demonstrate very good intersyngenic mating reactions with $P$. bibursaria which suggests that it correspond to Bomford's syngens B2.

Gene sequence: cytochrome $c$ oxidase subunit I sequence of the holotype specimen. Has been deposited in GenBank under JF708916 accession number.

Paramecium pentabursaria nov. spec.

Holotype: AZ20-1.

Type locality: Astrakhan Nature Reserve, Russia $\left(45^{\circ} 53^{\prime}\right.$ N $48^{\circ} 35^{\prime}$ E), backwaters in the delta of the Volga river.

Distribution: restricted to two location in Europe.

Occurrence/number of mating types: four mating types.

Corresponds to Bomford's syngen B3 or B5.

Gene sequence: cytochrome $c$ oxidase subunit I sequence of the holotype specimen. Has been deposited in GenBank under JF708905 accession number.

The current publication has been registered at ZooBank under the number: urn:lsid: zoobank.org:pub:5E000D59-AC98-4CB5-903E-F0251A01B6A4.

\section{Conclusions}

Sequence analysis of the gene encoding the COI mtDNA fragment from P. bursaria strains revealed that the mean genetic distance within the P. bursaria complex was 0.966 and the p-distance was greater than those observed for species from the P. aurelia and P. jenningsi complexes. Tree reconstruction demonstrated that the clade of the P. bursaria 
species complex is distinct from the other species of the genus Paramecium and is divided into two clades: the first, $P$. tribursaria, and the second containing the remaining species of the complex (P. bibursaria and P. tetrabursaria are sister subclades). The haplotype network has shown that cryptic species from the P. bursaria complex are separated from each other by as many as 68-87 different nucleotides. Haplotypes within individual cryptic species differ from each other by one to 22 substitutions. The P. bursaria complex, which represents extreme outbreeders, is believed to be a widespread taxon. It should be taken into account that the current research is based on 56 mainly Palearctic locations of $P$. bursaria species, and up-to-date Paramecium species sampling has not identified a P. bursaria complex in the tropics. Evaluation of the geographic distribution of members of the P. bursaria complex has revealed that two cryptic species, $P$. tetrabursaria and P. pentabursaria, have a limited range, while P. primabursaria, $P$. bibursaria, and $P$. tribursaria show a wider range of occurrence. The current study has confirmed that the COI mtDNA fragment is a good diagnostic tool for cryptic species identification in the P. bursaria species complex. Based on the results of the phylogenetic analyses, we decided to propose binominal names for each haplogroup of the morphospecies of P. bursaria: P. primabursaria, P. bibursaria, P. tribursaria, P. tetrabursaria, and P. pentabursaria.

Supplementary Materials: The following are available online at https:/ /www.mdpi.com/article/10 .3390/d13110589/s1, Table S1: Paramecium bursaria complex strains used in the current study [25, 29,36,75,95,96], Table S2: Paramecium strains (except P. bursaria) used in the current study $[16,36,59-$ 61,83,95,97-103]. Two Tetrahymena strains were used as outgroup, Table S3: p-distance matrix of the studied COI mtDNA fragments.

Author Contributions: Conceptualization, M.G.-S. and S.T.; methodology, M.R. and S.T.; software, S.T.; formal analysis, S.T.; investigation, M.G.-S., M.R., and S.T.; resources, M.R.; data curation, S.T.; writing—original draft preparation, S.T.; writing—review and editing, M.G.-S. and S.T.; visualization, S.T.; supervision, M.G.-S. All authors have read and agreed to the published version of the manuscript.

Funding: This research was funded by the Pedagogical University of Krakow and the Institute of Systematics and Evolution of Animals, Polish Academy of Sciences.

Institutional Review Board Statement: Not applicable.

Data Availability Statement: Not applicable.

Conflicts of Interest: The authors declare no conflict of interest.

\section{References}

1. Debroas, D.; Domaizon, I.; Humbert, J.-F.; Jardillier, L.; Lepère, C.; Oudart, A.; Taïb, N. Overview of freshwater microbial eukaryotes diversity: A first analysis of publicly available metabarcoding data. FEMS Microbiol. Ecol. 2017, 93, fix023. [CrossRef]

2. Finlay, B.J. Global dispersal of free-living microbial eucaryote species. Environ. Microbiol. 2002, 296, $1061-1064$.

3. Katz, L.A.; McManus, G.B.; Snoeyenbos-West, O.; Griffin, A.; Pirog, K.; Costas, B.; Foissner, W. Reframing the `Everything is everywhere' debate: Evidence for high gene flow and diversity in ciliate morphospecies. Aquat. Microb. Ecol. 2005, $41,55-65$. [CrossRef]

4. Schlegel, M.; Meisterfeld, R. The species problem in protozoa revisited. Eur. J. Protistol. 2003, 39, 349-355. [CrossRef]

5. Abraham, J.S.; Sripoorna, S.; Maurya, S.; Makhija, S.; Gupta, R.; Toteja, R. Techniques and tools for species identification in ciliates: A review. Int. J. Syst. Evol. Microbiol. 2019, 69, 877-894. [CrossRef] [PubMed]

6. Clamp, J.C.; Lynn, D.H. Investigating the biodiversity of ciliates in the 'Age of Integration'. Eur. J. Protistol. 2017, 61, 314-322. [CrossRef]

7. Doerder, F.P. Barcodes Reveal 48 New Species of Tetrahymena, Dexiostoma, and Glaucoma: Phylogeny, Ecology, and Biogeography of New and Established Species. J. Eukaryot. Microbiol. 2019, 66, 182-208. [CrossRef] [PubMed]

8. Lind, A.L.; Pollard, K.S. Accurate and sensitive detection of microbial eukaryotes from whole metagenome shotgun sequencing. Microbiome 2021, 9, 58. [CrossRef]

9. Schrallhammer, M. Biodiversity of Ciliates and Their Symbionts: A Special Issue. Diversity 2020, 12, 441. [CrossRef]

10. Barth, D.; Tischer, K.; Berger, H.; Schlegel, M.; Berendonk, T.U. High mitochondrial haplotype diversity of Coleps sp. (Ciliophora: Prostomatida). Environ. Microbiol. 2008, 10, 626-634. [CrossRef]

11. Gentekaki, E.; Lynn, D.H. Evidence for Cryptic Speciation in Carchesium polypinum Linnaeus, 1758 (Ciliophora: Peritrichia) Inferred from Mitochondrial, Nuclear, and Morphological Markers. J. Eukaryot. Microbiol. 2010, 57, 508-519. [CrossRef] 
12. Katz, L.A.; DeBerardinis, J.; Hall, M.S.; Kovner, A.M.; Dunthorn, M.; Muse, S.V. Heterogeneous Rates of Molecular Evolution Among Cryptic Species of the Ciliate Morphospecies Chilodonella uncinata. J. Mol. Evol. 2011, 73, 266-272. [CrossRef] [PubMed]

13. Boscaro, V.; Syberg-Olsen, M.J.; Irwin, N.A.T.; del Campo, J.; Keeling, P.J. What Can Environmental Sequences Tell Us About the Distribution of Low-Rank Taxa? The Case of Euplotes (Ciliophora, Spirotrichea), Including a Description of Euplotes enigma sp. nov. J. Eukaryot. Microbiol. 2019, 66, 281-293. [CrossRef]

14. Cai, X.; Wang, C.; Pan, X.; El-Serehy, H.A.; Mu, W.; Gao, F.; Qiu, Z. Morphology and systematics of two freshwater Frontonia species (Ciliophora, Peniculida) from northeastern China, with comparisons among the freshwater Frontonia spp. Eur. J. Protistol. 2018, 63, 105-116. [CrossRef]

15. Chen, Y.; Zhao, Y.; Pan, X.; Ding, W.; Rasheid, K.A.; Qiu, Z. Morphology and Phylogeny of a New Frontonia Ciliate, F. paramegna spec. nov. (Ciliophora, Peniculida) from Harbin Northeast China. Zootaxa 2014, 3827, 375-386. [CrossRef]

16. Krenek, S.; Berendonk, T.; Fokin, S. New Paramecium (Ciliophora, Oligohymenophorea) congeners shape our view on its biodiversity. Org. Divers. Evol. 2015, 15, 215-233. [CrossRef]

17. Liang, Z.; Shen, Z.; Zhang, Y.; Ji, D.; Li, J.; Warren, A.; Lin, X. Morphology and Phylogeny of Four New Vorticella Species (Ciliophora: Peritrichia) from Coastal Waters of Southern China. J. Eukaryot. Microbiol. 2019, 66, 267-280. [CrossRef] [PubMed]

18. Lynn, D.H.; Doerder, F.P.; Gillis, P.L.; Prosser, R.S. Tetrahymena glochidiophila n. sp., a new species of Tetrahymena (Ciliophora) that causes mortality to glochidia larvae of freshwater mussels (Bivalvia). Dis. Aquat. Org. 2018, 127, 125-136. [CrossRef]

19. Xu, Y.; Pan, H.; Miao, M.; Hu, X.; Al-Farraj, S.A.; Al-Rasheid, K.A.S.; Song, W. Morphology and Phylogeny of Two Species of Loxodes (Ciliophora, Karyorelictea), with Description of a New Subspecies, Loxodes striatus orientalis subsp. n. J. Eukaryot. Microbiol. 2015, 62, 206-216. [CrossRef] [PubMed]

20. Rataj, M.; Vd'ačný, P. Cryptic host-driven speciation of mobilid ciliates epibiotic on freshwater planarians. Mol. Phylogenet. Evol. 2021, 161, 107174. [CrossRef]

21. Bieliavskaia, A.; Kiselev, A.; Rautian, M. New Paramecium species “Candidatus Paramecium ossipovi”. Protistology 2016, 10, 8.

22. Paiva, T.S.; Borges, B.N.; Harada, M.L.; Silva-Nero, I.D. Description and molecular phylogeny of Paramecium grohmannae sp. nov. (Ciliophora, Peniculida) from a wastewater treatment plant in Brazil. Revista Brasileira de Zoociências Ciliophora 2016, 17, 7-19.

23. Shakoori, F.R.; Tasneem, F.; Al-Ghanim, K.; Mahboob, S.; Al-Misned, F.; Jahan, N.; Shakoori, A.R. Variability in Secondary Structure of 18S Ribosomal RNA as Topological Marker for Identification of Paramecium species. J. Cell. Biochem. 2014, 115, 2077-2088. [CrossRef]

24. Przyboś, E.; Tarcz, S. Paramecium jenningsi complex: Existence of three cryptic species confirmed by multi-locus analysis and strain crosses. Syst. Biodivers. 2016, 14, 140-154. [CrossRef]

25. Potekhin, A.; Mayén-Estrada, R. Paramecium Diversity and a New Member of the Paramecium aurelia Species Complex Described from Mexico. Diversity 2020, 12, 197. [CrossRef]

26. Fokin, S.; Przybos, E.; Chivilev, S.M.; Beier, C.L.; Horn, M.; Skotarczak, B.; Wodecka, B.; Fujishima, M. Morphological and molecular investigations of Paramecium schewiakoffi sp. nov. (Ciliophora, Oligohymenophorea) and current status of distribution and taxonomy of Paramecium spp. Eur. J. Protistol. 2004, 40, 22-243. [CrossRef]

27. Kreutz, M.; Stoeck, T.; Foissner, W. Morphological and Molecular Characterization of Paramecium (Viridoparamecium nov. subgen.) chlorelligerum Kahl (Ciliophora). J. Eukaryot. Microbiol. 2012, 59, 548-563. [CrossRef] [PubMed]

28. Sonneborn, T.M. The Paramecium aurelia complex of fourteen sibling species. Trans. Am. Microsc. Soc. 1975, 94, 155-178. [CrossRef]

29. Greczek-Stachura, M.; Potekhin, A.; Przyboś, E.; Rautian, M.; Skoblo, I.; Tarcz, S. Identification of Paramecium bursaria syngens through molecular markers-comparative analysis of three loci in the nuclear and mitochondrial DNA. Protist 2012, 163, 671-685. [CrossRef] [PubMed]

30. Tarcz, S.; Rautian, M.; Potekhin, A.; Sawka, N.; Beliavskaya, A.; Kiselev, A.; Nekrasova, I.; Przyboś, E. Paramecium putrinum (Ciliophora, Protozoa): The first insight into the variation of two DNA fragments-Molecular support for the existence of cryptic species. Mol. Phylogenet. Evol. 2014, 73, 140-145. [CrossRef] [PubMed]

31. Przyboś, E.; Rautian, M.; Beliavskaia, A.; Tarcz, S. Evaluation of the molecular variability and characteristics of Paramecium polycaryum and Paramecium nephridiatum, within subgenus Cypriostomum (Ciliophora, Protista). Mol. Phylogenet. Evol. 2019, 132, 296-306. [CrossRef]

32. Mayr, E. Systematics and the Origin of Species; Columbia University Press: New York, NY, USA, 1942.

33. Caron, D.A. Towards a Molecular Taxonomy for Protists: Benefits, Risks, and Applications in Plankton Ecology. J. Eukaryot. Microbiol. 2013, 60, 407-413. [CrossRef] [PubMed]

34. Fokin, S. Paramecium genus: Biodiversity, some morphological features and the key to the main morphospecies discrimination. Protistology 2010, 6, 227-235.

35. Zhan, Z.; Li, J.; Xu, K. Ciliate Environmental Diversity Can Be Underestimated by the V4 Region of SSU rDNA: Insights from Species Delimitation and Multilocus Phylogeny of Pseudokeronopsis (Protist, Ciliophora). Microorganisms 2019, 7, 493. [CrossRef]

36. Strüder-Kypke, M.C.; Lynn, D.H. Comparative analysis of the mitochondrial cytochrome c oxidase subunit I (COI) gene in ciliates (Alveolata, Ciliophora) and evaluation of its suitability as a biodiversity marker. Syst. Biodivers. 2010, 8, 131-148. [CrossRef]

37. Park, M.-H.; Jung, J.-H.; Jo, E.; Park, K.-M.; Baek, Y.-S.; Kim, S.-J.; Min, G.-S. Utility of mitochondrial CO1 sequences for species discrimination of Spirotrichea ciliates (Protozoa, Ciliophora). Mitochondrial DNA Part A 2019, 30, 148-155. [CrossRef] [PubMed]

38. Przyboś, E.; Tarcz, S. Global molecular variation of Paramecium jenningsi complex (Ciliophora, Protista): A starting point for further, detailed biogeography surveys. Syst. Biodivers. 2019, 17, 527-539. [CrossRef] 
39. Focke, G.W. Ueber einige organisations-verhaltnisse bei polygastrischen infusorien. Oken. Isis 1836, 10, 785-787.

40. Vivier, E. Morphology, Taxonomy and General Biology of the Genus Paramecium. In Paramecium, A Current Survey; van Wagtendonk, W.J., Ed.; Elsevier: Amsterdam, The Netherlands, 1974; pp. 1-89.

41. Wichterman, R. The Biology of Paramecium, 2nd ed.; Plenum Press: New York, NY, USA, 1986.

42. Greczek-Stachura, M.; Leśnicka, P.Z.; Tarcz, S.; Rautian, M.; Możdżeń, K. Genetic Diversity of Symbiotic Green Algae of Paramecium bursaria Syngens Originating from Distant Geographical Locations. Plants 2021, 10, 609. [CrossRef]

43. Pröschold, T.; Darienko, T.; Silva, P.C.; Reisser, W.; Krienitz, L. The systematics of Zoochlorella revisited employing an integrative approach. Environ. Microbiol. 2011, 13, 350-364. [CrossRef]

44. Bomford, R. The Syngens of Paramecium bursaria: New Mating Types and Intersyngenic Mating Reactions. J. Protozool. 1966, 13, 497-501. [CrossRef] [PubMed]

45. Sonneborn, T.M. Breeding systems, reproductive methods and species problem in Protozoa. In The Species Problem; Mayer, E., Ed.; AAAS: Washington, DC, USA, 1957; pp. 155-324.

46. Sonneborn, T.M. Chapter 12 Methods in Paramecium Research. In Methods in Cell Biology; Prescott, D.M., Ed.; Academic Press: New York, NY, USA, 1970; Volume 4, pp. 241-339.

47. Hall, T.A. BioEdit: A User-Friendly Biological Sequence Alignment Editor and Analysis Program for Windows 95/98/NT. Nucleic Acids Symp. Ser. 1999, 41, 95-98.

48. Tamura, K.; Stecher, G.; Peterson, D.; Filipski, A.; Kumar, S. MEGA6: Molecular Evolutionary Genetics Analysis Version 6.0. Mol. Biol. Evol. 2013, 30, 2725-2729. [CrossRef]

49. Ronquist, F.; Huelsenbeck, J.P. MrBayes 3: Bayesian phylogenetic inference under mixed models. Bioinformatics 2003, 19, 1572-1574. [CrossRef]

50. Page, R.D.M. Tree View: An application to display phylogenetic trees on personal computers. Bioinformatics 1996, 12, 357-358. [CrossRef] [PubMed]

51. Librado, P.; Rozas, J. DnaSP v5: A software for comprehensive analysis of DNA polymorphism data. Bioinformatics 2009, 25, 1451-1452. [CrossRef] [PubMed]

52. Bandelt, H.J.; Forster, P.; Röhl, A. Median-joining networks for inferring intraspecific phylogenies. Mol. Biol. Evol. 1999, 16, 37-48. [CrossRef]

53. Leigh, J.W.; Bryant, D. popart: Full-feature software for haplotype network construction. Methods Ecol. Evol. 2015, 6, 1110-1116. [CrossRef]

54. Hebert, P.D.N.; Cywinska, A.; Ball, S.L.; deWaard, J.R. Biological identifications through DNA barcodes. Proc. Biol. Sci. 2003, 270, 313-321. [CrossRef] [PubMed]

55. Moritz, C.; Cicero, C. DNA Barcoding: Promise and Pitfalls. PLoS Biol. 2004, 2, e354. [CrossRef]

56. Pawlowski, J.; Audic, S.; Adl, S.; Bass, D.; Belbahri, L.; Berney, C.; Bowser, S.S.; Cepicka, I.; Decelle, J.; Dunthorn, M.; et al. CBOL Protist Working Group: Barcoding Eukaryotic Richness beyond the Animal, Plant, and Fungal Kingdoms. PLoS Biol. 2012, 10, e1001419. [CrossRef] [PubMed]

57. Stoeck, T.; Przybos, E.; Dunthorn, M. The D1-D2 region of the large subunit ribosomal DNA as barcode for ciliates. Mol. Ecol. Resour. 2014, 14, 458-468. [CrossRef] [PubMed]

58. Coleman, A.W. Paramecium aurelia Revisited. J. Eukaryot. Microbiol. 2005, 52, 68-77. [CrossRef]

59. Boscaro, V.; Fokin, S.I.; Verni, F.; Petroni, G. Survey of Paramecium duboscqui using three markers and assessment of the molecular variability in the genus Paramecium. Mol. Phylogenet. Evol. 2012, 65, 1004-1013. [CrossRef]

60. Tarcz, S.; Potekhin, A.; Rautian, M.; Przyboś, E. Variation in ribosomal and mitochondrial DNA sequences demonstrates the existence of intraspecific groups in Paramecium multimicronucleatum (Ciliophora, Oligohymenophorea). Mol. Phylogenet. Evol. 2012, 63, 500-509. [CrossRef] [PubMed]

61. Barth, D.; Krenek, S.; Fokin, S.I.; Berendonk, T.U. Intraspecific Genetic Variation in Paramecium Revealed by Mitochondrial Cytochrome c Oxidase I Sequences. J. Eukaryot. Microbiol. 2006, 53, 20-25. [CrossRef]

62. Brown, W.M.; George, M., Jr.; Wilson, A.C. Rapid evolution of animal mitochondrial DNA. Proc. Natl. Acad. Sci. USA 1979, 76, 1967-1971. [CrossRef]

63. De Souza, B.A.; Dias, R.J.P.; Senra, M.V.X. Intrageneric evolutionary timing and hidden genetic diversity of Paramecium lineages (Ciliophora: Oligohymenophorea). Syst. Biodivers. 2020, 18, 662-674. [CrossRef]

64. Bickford, D.; Lohman, D.J.; Sodhi, N.S.; Ng, P.K.L.; Meier, R.; Winker, K.; Ingram, K.K.; Das, I. Cryptic species as a window on diversity and conservation. Trends Ecol. Evol. 2007, 22, 148-155. [CrossRef]

65. Grundt, H.H.; Kjølner, S.; Borgen, L.; Rieseberg, L.H.; Brochmann, C. High biological species diversity in the arctic flora. Proc. Natl. Acad. Sci. USA 2006, 103, 972-975. [CrossRef] [PubMed]

66. Hebert, P.D.N.; Penton, E.H.; Burns, J.M.; Janzen, D.H.; Hallwachs, W. Ten species in one: DNA barcoding reveals cryptic species in the neotropical skipper butterfly Astraptes fulgerator. Proc. Natl. Acad. Sci. USA 2004, 101, 14812-14817. [CrossRef] [PubMed]

67. Amato, A.; Kooistra, W.H.C.F.; Levialdi Ghiron, J.H.; Mann, D.G.; Pröschold, T.; Montresor, M. Reproductive Isolation among Sympatric Cryptic Species in Marine Diatoms. Protist 2007, 158, 193-207. [CrossRef]

68. Smirnov, A.V. Cryptic freshwater amoeba species in the bottom sediments of Nivå Bay (Øresund, Baltic Sea). Europ. J. Protistol. 2007, 43, 87-94. [CrossRef] 
69. Chantangsi, C.; Lynn, D.H.; Brandl, M.T.; Cole, J.C.; Hetrick, N.; Ikonomi, P. Barcoding ciliates: A comprehensive study of 75 isolates of the genus Tetrahymena. Int. J. Syst. Evol. Microbiol. 2007, 57, 2412-2423. [CrossRef] [PubMed]

70. McManus, G.B.; Xu, D.; Costas, B.A.; Katz, L.A. Genetic Identities of Cryptic Species in the Strombidium stylifer/apolatum/oculatum Cluster, Including a Description of Strombidium rassoulzadegani n. sp. J. Eukaryot. Microbiol. 2010, 57, 369-378. [CrossRef]

71. Foissner, W.; Chao, A.; Katz, L.A. Diversity and geographic distribution of ciliates (Protista: Ciliophora). Biodivers. Conserv. 2008, 17, 345-363. [CrossRef]

72. Allen, S.; Farrow, S.W.; Golembiowski, P.A. Esterase variation between the 14 syngens of Paramecium aurelia under axenic growth Genetics 1973, 73, 561-573. [CrossRef]

73. Tait, A. Enzyme variation between syngens in Paramecium aurelia. Biochem. Genet. 1970, 4, 461-470. [CrossRef] [PubMed]

74. Catania, F.; Wurmser, F.; Potekhin, A.A.; Przyboś, E.; Lynch, M. Genetic Diversity in the Paramecium aurelia Species Complex. Mol. Biol. Evol. 2008, 26, 421-431. [CrossRef]

75. Zagata, P.; Greczek-Stachura, M.; Tarcz, S.; Rautian, M. Molecular Identification of Paramecium bursaria Syngens and Studies on Geographic Distribution using Mitochondrial Cytochrome C Oxidase Subunit I (COI). Folia Biol. 2015, 63, 77-83. [CrossRef]

76. Olefeld, J.L.; Bock, C.; Jensen, M.; Vogt, J.C.; Sieber, G.; Albach, D.; Boenigk, J. Centers of endemism of freshwater protists deviate from pattern of taxon richness on a continental scale. Sci. Rep. 2020, 10, 14431. [CrossRef]

77. Finlay, B.J. The global diversity of protozoa and other small species. Int. J. Parasitol. 1998, 28, 29-48. [CrossRef]

78. Foissner, W. Biogeography and Dispersal of Micro-organisms: A Reviev Emphasizing Protists. Acta Protozool. 2006, 45, 111-136.

79. Segawa, T.; Matsuzaki, R.; Takeuchi, N.; Akiyoshi, A.; Navarro, F.; Sugiyama, S.; Yonezawa, T.; Mori, H. Bipolar dispersal of red-snow algae. Nat. Commun. 2018, 9, 3094. [CrossRef]

80. Dunthorn, M.; Stoeck, T.; Wolf, K.; Breiner, H.-W.; Foissner, W. Diversity and endemism of ciliates inhabiting Neotropical phytotelmata. Syst. Biodivers. 2012, 10, 195-205. [CrossRef]

81. Przyboś, E.; Tarcz, S.; Dusi, E. New Paramecium quadecaurelia strains (P. aurelia spp. complex, Ciliophora) identified by molecular markers (rDNA and mtDNA). Europ. J. Protistol. 2013, 49, 477-486. [CrossRef] [PubMed]

82. Przyboś, E.; Tarcz, S.; Rautian, M.; Lebedeva, N. The first European stand of Paramecium sonneborni (P. aurelia complex), a species known only from North America (Texas, USA). Europ. J. Protistol. 2014, 50, 236-247. [CrossRef]

83. Tarcz, S.; Przyboś, E.; Surmacz, M. An assessment of haplotype variation in ribosomal and mitochondrial DNA fragments suggests incomplete lineage sorting in some species of the Paramecium aurelia complex (Ciliophora, Protozoa). Mol. Phylogenet. Evol. 2013, 67, 255-265. [CrossRef] [PubMed]

84. Salsbery, M.E.; DeLong, J.P. The benefit of algae endosymbionts in Paramecium bursaria is temperature dependent. Evol. Ecol. Res. 2018, 19, 669-678.

85. Możdżeń, K.; Leśnicka, P.Z.; Burnecki, T.; Śliwińska-Wilczewska, S.; Skoczowski, A.; Greczek-Stachura, M. Photosynthetic efficiency of endosymbiotic algae of Paramecium bursaria originating from locations with cold and warm climates. Oceanol. Hydrobiol. Stud. 2018, 47, 202-210. [CrossRef]

86. Tarcz, S.; Sawka-Gądek, N.; Przyboś, E. Worldwide sampling reveals low genetic variability in populations of the freshwater ciliate Paramecium biaurelia (P. aurelia species complex, Ciliophora, Protozoa). Org. Divers. Evol. 2018, 18, 39-50. [CrossRef]

87. de Puytorac, P.; Batisse, A.; Bohatier, J.; Corliss, J.O.; Deroux, G.; Didier, P.; Dragesco, J.; Fryd-Versavel, G.; Grain, J.; Grolière, C.; et al. Proposition dúne classification du phylum Ciliophora Doflein, 1901 (réunion de systématique, Clermont-Ferrand). C. r. hebd. Séanc. Acad. Sci. Paris 1974, 278, 2799-2802.

88. Corliss, J.O. On the evolution and systematics of ciliated protozoa. Syst. Zool. 1956, 5, 68-91. [CrossRef]

89. Dujardin, F. Histoire Naturelle Des Zoophytes; Suies a Buffon; Infusoires: Paris, France, 1841.

90. Müller, O.F. Vermium Terrestrium et Fluviatilium, seu Animalium Infusorium, Helminthicorum et Testaceorum, non Marinorum, Succincta Historia. Havniae et Lipsiae 1773, 1, 1-135.

91. Fokin, S.I. Morphology of the contractile vacuoles in ciliated protozoa of the genus Paramecium (Hymenostomatida, Peniculina) as a species-specific character. Zool. Zhurnal 1986, 65, 5-15.

92. Engelmann, T.W. Über Licht- und Farbenperception niederster Organismen. Archiv. Physiol. 1882, 2, 387-400. [CrossRef]

93. Pado, R. Spectral activity of light and phototaxis in Paramecium bursaria. Acta Protozool. 1972, 11, 387-393.

94. Nakaoka, Y. Localization of photosensitivity in Paramecium. J. Comp. Physiol. A 1989, 165, 637-641. [CrossRef]

95. Barth, D.; Berendonk, T.U. The mitochondrial genome sequence of the ciliate Paramecium caudatum reveals a shift in nucleotide composition and codon usage within the genus Paramecium. BMC Genom. 2011, 12, 272. [CrossRef] [PubMed]

96. Zhao, Y.; Gentekaki, E.; Yi, Z.; Lin, X. Genetic differentiation of the mitochondrial cytochrome oxidase c subunit I gene in genus Paramecium (Protista, Ciliophora). PLoS ONE 2013, 8, e77044. [CrossRef] [PubMed]

97. Przyboś, E.; Tarcz, S.; Pothekin, A.; Rautian, M.; Prajer, M. A two-locus molecular characterisation of Paramecium calkinsi. Protist 2012, 163, 263-273. [CrossRef]

98. Przyboś, E.; Tarcz, S.; Rautian, M.; Sawka, N. Delimiting species boundaries within a paraplyletic species complex: Insights from morphological, genetic, and molecular data on Paramecium sonneborni (Paramecium aurelia species complex, Ciliophora, Protozoa). Protist 2015, 166, 438-456. [CrossRef]

99. Tarcz, S. Intraspecific differentiation of Paramecium novaurelia strains (Ciliophora, Protozoa) inferred from phylogenetic analysis of ribosomal and mitochondrial DNA variation. Europ. J. Protistol. 2013, 49, 50-56. [CrossRef] [PubMed] 
100. Przyboś, E.; Tarcz, S. Three-locus analysis in conjunction with strain crosses confirms the existence of reproductively isolated populations in Paramecium jenningsi (Diller and Earl 1958). Syst. Biodivers. 2013, 11, 507-523. [CrossRef]

101. Snoke, M.S.; Berendonk, T.U.; Barth, D.; Lynch, M. Large Global Effective Population Sizes in Paramecium. Mol. Biol. Evol. 2006, 23, 2474-2479. [CrossRef] [PubMed]

102. Krenek, S.; Petzoldt, T.; Berendonk, T.U. Coping with Temperature at the Warm Edge-Patterns of Thermal Adaptation in the Microbial Eukaryote Paramecium caudatum. PLoS ONE 2012, 7, e30598. [CrossRef]

103. Kher, C.P.; Doerder, F.P.; Cooper, J.; Ikonomi, P.; Achilles-Day, U.; Kupper, F.C.; Lynn, D.H. Barcoding Tetrahymena: Discriminating species and identifying unknowns using the cytochrome c oxidase subunit I (cox-1) barcode. Protist 2011, 162, 2-13. [CrossRef] 